\title{
Endotoxin Triggers Tumor Initiation Events in Nontumorigenic Breast Epithelial Cells and Enhances Invasion-Related Phenotype in Pretumorigenic and Tumorigenic Breast Epithelial Cells
}

\author{
Farah Yassine $\mathbb{D}$, Sabreen F. Fostok $\mathbb{D}$, Nataly Naser Al Deen $\mathbb{D}$, and Rabih S. Talhouk \\ American University of Beirut (AUB), Department of Biology, Beirut, Lebanon \\ Correspondence should be addressed to Rabih S. Talhouk; rtalhouk@aub.edu.lb
}

Received 12 May 2021; Revised 28 October 2021; Accepted 12 November 2021; Published 26 November 2021

Academic Editor: Hong Zan

Copyright $(2) 2021$ Farah Yassine et al. This is an open access article distributed under the Creative Commons Attribution License, which permits unrestricted use, distribution, and reproduction in any medium, provided the original work is properly cited.

\begin{abstract}
Inflammation is associated with the development of several cancers, including breast cancer. However, the molecular mechanisms driving breast cancer initiation or enhancement by inflammation are yet to be deciphered. Hence, we opted to investigate the role of inflammation in initiating and enhancing tumor-like phenotypes in nontumorigenic, pretumorigenic, and tumorigenic breast epithelial cells. Noncytotoxic endotoxin (ET) concentrations capable of inducing an inflammatory phenotype were determined for the different cell lines. Results showed that short-term ET exposure upregulated matrix metalloproteinase-9 (MMP-9) activity in nontumorigenic mammary epithelial cells of mouse (SCp2) and human origins (HMT-3522 S1; S1) and upregulated inflammatory mediators including nitric oxide (NO) and interleukin 1- $\beta$ in tumorigenic human breast cells (MDA-MB-231), all in a dose-dependent manner. Long-term ET treatment, but not short-term, triggered the migration of SCp2 cells, and proliferation and migration of tumorigenic human breast cells MCF-7 and MDA-MB-231. Both short- and long-term ET exposures preferentially enhanced the invasion of pretumorigenic S1-connexin 43 knockout (Cx43-KO S1) cells compared to their nontumorigenic S1 counterparts. Moreover, both ET exposures disrupted lumen formation and apicolateral distribution of $\beta$-catenin in 3D cultures of S1 cells. In conclusion, ET treatment at concentrations that elicited inflammatory phenotype triggered tumor initiation events in nontumorigenic and pretumorigenic breast cells, and increased tumorigenicity of breast cancer cells. Our findings highlight the role of inflammation in enhancing migration, invasion, and loss of normal 3D morphology and suggest that such inflammatory insults can "add injury" to pretumorigenic and tumorigenic breast epithelial cells.
\end{abstract}

\section{Introduction}

Inflammation is implicated in the initiation processes of several cancers [1]. Specifically, chronic inflammation has long been associated with cancer development [2]. For instance, the risk of developing colorectal cancer increases with inflammatory bowel diseases such as ulcerative colitis and Crohn's disease $[3,4]$. The risk of hepatocellular carcinoma is also more pronounced in the setting of chronic hepatitis and cirrhosis [5]. Similarly, gastric inflammation caused by Helicobacter pylori infection has been linked to gastric malignancies [6].
Endotoxin (ET), a lipopolysaccharide constituent of Gram-negative bacterial cell wall, is a known inflammatory trigger implicated in cancer invasion and angiogenesis [7-9]. Chronic exposure to ET was shown to promote lung tumorigenesis [10], and by affecting key determinants of metastasis, ET was shown to enhance migration of prostate cancer cells [11].

Among all cancer types, breast cancer is the most common and the second cause of cancer-related deaths in women after lung cancer worldwide [12]. A complex relationship has been described between inflammation and breast cancer risk [13]. For example, elevated levels of 
C-reactive protein, an inflammatory marker, were associated with an increase in the risk of breast cancer [14]. However, the association between chronic inflammation and transition of the normal breast epithelium into neoplastic tissue is not well understood. Studies showed the involvement of the inflammatory microenvironment in the malignant progression of breast cancer [15]. Thus, studying the inflammatory biomarkers, cellular mediators, and their downstream effects due to a chronic insult is important for understanding cancer initiation [16].

In light of the above, little is known about the effect of ET-induced chronic inflammation on breast cancer initiation events and whether such inflammation would trigger loss of $3 \mathrm{D}$ morphological differentiation and apical polarity that characterize normal breast tissue.

Previous studies by our laboratory showed that ET-activated NF-kB suppressed $\beta$-casein expression and upregulated gelatinases, cytokines, nerve growth factor (NGF), and nitric oxide (NO) in rodent mammary cells $[17,18]$. Thus, we opted to study the effect of short- and long-term ET inflammatory challenge in nontumorigenic, pretumorigenic, and tumorigenic human breast epithelial cell lines. We propose that ET-induced inflammation enhances the tumor initiation events in nontumorigenic and pretumorigenic mammary epithelial cells and increases tumorigenicity of breast cancer cell lines, suggesting that inflammatory insults not only trigger tumor initiation events but can also "add injury" to pretumorigenic and tumorigenic breast cells.

\section{Materials and Methods}

2.1. Cell Culture. For the nontumorigenic mouse mammary epithelial cell (SCp2) culture, low passage numbers (18-25) of SCp2 cells were used throughout. Cells (kindly provided by P. Y. Desprez, Geraldine Brush Cancer Research Institute, California Pacific Medical Center, San Francisco, CA) were maintained and propagated as described by Maalouf et al. [17].

For nontumorigenic human breast cells HMT-3522 S1 (S1) and pretumorigenic S1-connexin 43 knockout (Cx43KO S1) cultures, methods by Fostok et al. [19] were followed for both two-dimensional (2D) and 3D conditions. Cells were kindly provided by Dr. Sophie Lelievre (Purdue University, IN).

For tumorigenic human breast cells MDA-MB-231 and MCF-7 cultures, kindly provided by Dr. Mina Bissell (Lawrence Berkeley National Laboratory, LBNL, CA), low passage numbers (18-30) were grown in humidified incubator (95\% air, 5\% CO2) at $37^{\circ} \mathrm{C}$, in RPMI 1640 media (Lonza, Belgium) supplemented with $1 \%$ penicillin-streptomycin (Pen-Strep) and 10\% fetal bovine serum (FBS). The medium was changed once every two days, and cells were transferred at $80 \%$ confluence.

Short-term ET exposure consisted of ET treatment for 48 hours after acquisition of $70-80 \%$ confluence, after which conditioned media were collected and assayed, whereas long-term exposure consisted of a continuous ET treatment for a one-month period of time, replenished with every change of media, in an attempt to mimic chronic inflammation. For all ET treatments, ET was added at concentrations $(0.1-10 \mu \mathrm{g} / \mathrm{ml})$ that did not affect cell viability while eliciting an inflammatory response.

\subsection{Zymography Assay (Substrate-Gel Electrophoresis).} Culture media were collected from the respective cultures and stored at $-80^{\circ} \mathrm{C}$. Gelatinase activity in the collected media was analyzed using the method described by Talhouk et al. [20]. Equal sample volumes mixed in $1: 1$ ratio $(\mathrm{V} / \mathrm{V})$ with $2 \mathrm{X}$ sample buffer were loaded and run on $7 \%$ polyacrylamide gels impregnated with gelatin $(4.5 \mathrm{mg} / \mathrm{ml})$. The gelatinases appeared as clear white bands on darkly stained blue gels; then, colors were inverted using ImageJ (http:// imagej.nih.gov/ij/) software in order to visualize the gelatinases as black bands against a white background as presented. Peak areas of MMP bands were quantified using Image $\mathrm{I}$ in triplicate, and data were represented as the average fold increase of MMP band peak area (Arbitrary Basal Density) of three independent experiments \pm standard deviation $(S D)(A U \pm S D)$.

2.3. Wound Healing Assay. Untreated cells and those subjected to long-term ET treatment were plated in 6-well plates at a density of $2.5 \times 10^{5}$ cells $/ \mathrm{ml}$ in their respective culture media (DMEM/F12 containing 1\% Pen-Strep, 5\% FBS, and $0.1 \%$ insulin for SCp2 cells and RPMI 1640 supplemented with 1\% Pen-Strep and 10\% FBS for MDA-MB-231 and MCF-7 cells). Culture media of cells subjected to long-term ET treatment were also supplemented with $0.1 \mu \mathrm{g} / \mathrm{ml}$ ET for SCp2 cells and $1 \mu \mathrm{g} / \mathrm{ml}$ ET for MDA-MB-231 and MCF-7 cells. After 72 hours, upon reaching full confluence, cells were washed twice with phosphate buffered saline (PBS) 1X and then supplemented with growth media containing $1 \%$ Pen-Strep and 1\% FBS. Control cells were left untreated, and another group was subjected to short-term ET exposure by supplementing their culture media with $0.1 \mu \mathrm{g} / \mathrm{ml}$ of ET for SCp2 cells and $1 \mu \mathrm{g} / \mathrm{ml}$ ET for MDA-MB-231 and MCF-7 cells. Culture media of cells subjected to long-term ET treatment were also supplemented with ET as before. At the same time, a straight wound was made using a $200 \mu$ l pipette tip, and the wound site was monitored throughout time at 2 , 6,12 , and 48 hours after wounding. Pictures were taken using a light microscope, and the closure of the wounded area was measured 48 hours after wounding using ImageJ.

2.4. Invasion Assay. As reported by Fostok et al. [19], 6-well tissue-culture plates were fitted with inserts $(8 \mu \mathrm{m}$ pore size). The inserts were coated with $400 \mu$ of [Matrigel] EngelbrethHolm-Swarm (EHS) growth media solution of $1: 20$ ratio and incubated at $37^{\circ} \mathrm{C}$ for 4 hours; $3 \times 10^{5} \mathrm{~S} 1$ cells were seeded in the inserts. After 24 hours, the cells were fixed using 4\% formaldehyde in PBS $1 \mathrm{X}$ for 20 minutes at room temperature. The cells towards the inside of the insert were removed by using a cotton swab, and nuclei of migrated cells were counterstained with Hoechst 33342 (Molecular Probes, $\mathrm{H} 3570$ ) at a concentration of $0.5 \mu \mathrm{g} / \mathrm{ml}$ for 10 minutes at room temperature. The insert was then cut and mounted on 
a microscopic slide in ProLong ${ }^{\circledR}$ Gold antifade reagent (Invitrogen Molecular Probes). The inserts were then examined by fluorescence microscopy.

2.5. Immunofluorescence Labeling. $\mathrm{S} 1$ acini from fresh 3D cultures on day 11 were permeabilized with $0.5 \%$ peroxide and carbonyl-free Triton X-100 (Sigma-Aldrich) in cytoskeleton buffer $(100 \mathrm{mM} \mathrm{NaCl}, 300 \mathrm{mM}$ sucrose, $10 \mathrm{mM}$ PIPES, pH 6.8, $5 \mathrm{mM} \mathrm{MgCl}_{2}, 1 \mathrm{mM}$ Pefabloc, $10 \mu \mathrm{g} / \mathrm{ml}$ aprotinin, $250 \mu \mathrm{M} \mathrm{NaF}$ ) prior to fixation in $4 \%$ formaldehyde (Sigma-Aldrich). Antibodies used were rabbit polyclonal $\beta$-catenin $(1: 100$, Santa Cruz Biotechnology, $200 \mu \mathrm{g} /$ $\mathrm{ml})$. Donkey anti-rabbit secondary antibody conjugated to Alexa Fluor 568 (red) (Invitrogen Molecular Probes, Eugene, OR) was used at the manufacturer's proposed dilution (1: $2,000)$. Nuclei were counterstained with $0.5 \mu \mathrm{g} / \mathrm{ml}$ Hoechst 33342 (Molecular Probes, H3570), and specimens were mounted in ProLong ${ }^{\circledR}$ Gold antifade reagent (Invitrogen Molecular Probes). A minimum of one hundred acini were analyzed for each immunostaining using laser scanning confocal microscope (LSCM). Images of immunofluorescence labeling were recorded using LSCM (LSM 410, Zeiss, Germany). Images were processed using ZEN lite software and Image and assembled using Adobe Photoshop ${ }^{\circledR} 6.0$ (Adobe Systems, San Jose, CA).

2.6. Griess Reaction Assay of Nitric Oxide for Nitric Oxide Synthase Activity. Untreated MDA-MB-231 cells were plated in 6-well plates at a density of $2.5 \times 10^{5}$ cells $/ \mathrm{ml}$ in RPMI 1640 culture media supplemented with $1 \%$ Pen-Strep and 10\% FBS. After 24 hours, cells were washed twice with PBS 1X and then supplemented with RPMI 1640 containing 1\% Pen-Strep and $1 \%$ FBS. MDA-MB-231 cells were either left as control untreated cells or subjected to short-term ET exposure by supplementing their culture media with 0.1 or $1 \mu \mathrm{g} / \mathrm{ml}$ ET. Conditioned media were collected 48 hours after treatment [17].

The analysis of NO was done by the Griess assay that measures nitrite (the stable spontaneous oxidation product of NO) using a Griess Reagent Kit (Molecular Probes, Eugene, OR) according to the manufacturer's protocol. Samples were assayed in duplicate, and data were represented as the average concentration of $\mathrm{NO}_{2}^{-}$of three independent experiments $\pm \mathrm{SD}(\mu \mathrm{g} \pm \mathrm{SD})$.

2.7. Enzyme-Linked Immunosorbent Assay. To measure interleukin $1-\beta$ (IL-1 $\beta$ ) secretion in response to ET in MDAMB-231 cells, media collected 48 hours after ET treatment (as described above) were assayed by enzyme-linked immunosorbent assay (ELISA) for IL- $1 \beta$ (DuoSet Kit; R\&D Systems Inc., Minneapolis, MN) according to the manufacturer's protocol. Samples were assayed in duplicate, and data were represented as the average IL- $1 \beta(\mathrm{pg}) / 10^{6}$ cells of three independent experiments $\pm \mathrm{SD}$.

2.8. Statistical Analysis. Data were presented as means $\pm \mathrm{SD}$, and statistical comparisons were done using Microsoft Excel. Unpaired or paired $t$-test was used for comparison of two groups, whereas one-way analysis of variance (ANOVA) with Tukey test was employed for three or more groups of treatment with one independent variable. Significance levels were at ${ }^{*} p<0.05,{ }^{* *} p<0.01$, and ${ }^{* * *} p<0.001$.

\section{Results}

Noncytotoxic ET concentrations that elicit an inflammatory response without affecting cell viability were determined for the different cell lines used in this study. Subsequently, ET was used at $0.1 \mu \mathrm{g} / \mathrm{ml}$ for the treatment of normal mouse mammary epithelial SCp2 cells, at $10 \mu \mathrm{g} / \mathrm{ml}$ for nontumorigenic human mammary epithelial S1 cells and their pretumorigenic counterparts, $\mathrm{Cx} 43-\mathrm{KO} S 1$ cells [21], and at $1 \mu \mathrm{g} / \mathrm{ml}$ for the tumorigenic cell lines including human breast cancer cells of intermediate (MCF-7) and high invasiveness (MDA-MB-231).

3.1. Short-Term Treatment with Endotoxin Enhances MMP-9 Levels in Conditioned Media of Normal Mouse (SCp2) and Nontumorigenic Human Mammary Epithelial Cells (S1). SCp2 cells, capable of differentiation upon optimal cell-cell and cell-matrix interactions [22], were treated with $0.1,0.5$, or $1 \mu \mathrm{g} / \mathrm{ml} \mathrm{ET} \mathrm{for} 48$ hours (short-term exposure), after which conditioned media were assayed for MMP-9 by zymography. Active MMP-9 levels were upregulated upon treatment with $0.1,0.5$, and $1 \mu \mathrm{g} / \mathrm{ml}$ of ET compared to the untreated control. Quantification of resolved bands denoted $\sim 2-, 4-$, and 6-fold increase in MMP-9 activity in conditioned media of SCp2 cells treated with $0.1,0.5$, and $1 \mu \mathrm{g} / \mathrm{ml}$ of ET, respectively, as compared to the untreated control cells (Figures 1(a) and 1(b)). Similarly, active MMP-9 levels in conditioned media of S1 cells were upregulated upon treatment with ET compared to the untreated control. Quantification of the resolved bands denoted 4.5-, 4.9-, 7.4-, and 10-fold increase in MMP-9 activity in conditioned media of S1 cells treated with $5,10,15$, and $20 \mu \mathrm{g} / \mathrm{ml}$ of ET, respectively, as compared to the untreated control cells (Figures 1(c) and 1(d)).

3.2. Short-Term Exposure to Endotoxin Induces an Inflammatory Response in Human Breast Cancer MDA-MB-231 Cells. Short-term (48-hour) treatment with either 0.1 or $1 \mu \mathrm{g} / \mathrm{ml}$ ET in tumorigenic MDA-MB-231 human breast cells increased the levels of inflammatory mediators, namely, NO and IL1- $\beta$. Quantification of the zymography bands denoted an upward, yet non-statistically significant, trend of 1.5-1.7-fold increase in MMP-9 activity in conditioned media of MDA-MB-231 cells treated with 0.1 and $1 \mu \mathrm{g} / \mathrm{ml}$, respectively, as compared to untreated control cells (Figures 2(a) and 2(b)). The levels of NO significantly increased from $3.9 \mu \mathrm{g} / 10^{6}$ cells in conditioned media of control untreated MDA-MB-231 cells to $13.1 \mu \mathrm{g} / 10^{6}$ cells when treated with $0.1 \mu \mathrm{g} / \mathrm{ml}$ ET. A 5 -fold increase in NO level $\left(20 \mu \mathrm{g} / 10^{6}\right.$ cells) was noted when treated with $1 \mu \mathrm{g} / \mathrm{ml} \mathrm{ET}$ (Figure 2(c)). Levels of IL1- $\beta$ increased from $0.1 \mathrm{pg} / 10^{6}$ cells in conditioned media of untreated cells to $0.9 \mathrm{pg} / 10^{6}$ cells when treated with $0.1 \mu \mathrm{g} / \mathrm{ml}$ ET. Cells treated with $1 \mu \mathrm{g} / \mathrm{ml}$ 


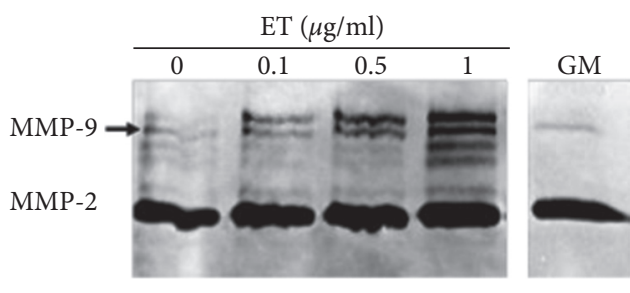

(a)

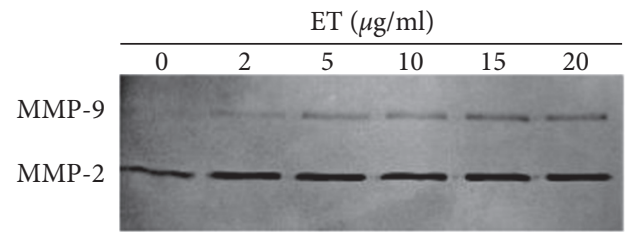

(c)

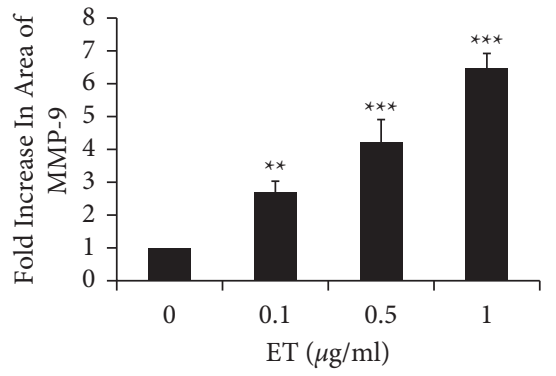

(b)

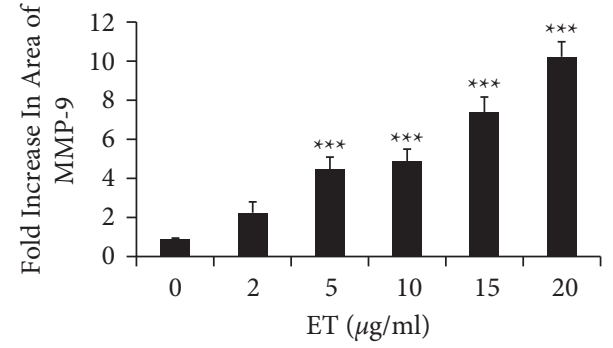

(d)

FIGURE 1: Short-term treatment with endotoxin induces MMP-9 activity in normal mouse (SCp2) and human (S1) mammary epithelial cells. Gelatin zymography of (a) SCp2 and (c) S1 conditioned media collected from untreated control cells $(0 \mu \mathrm{g} / \mathrm{ml})$ and ET-treated cells $(0.1,0.5$, and $1 \mu \mathrm{g} / \mathrm{ml}$ for SCp2 cells; 2, 5, 10, 15, and $20 \mu \mathrm{g} / \mathrm{ml}$ for S1 cells) upon reaching $75 \%$ confluence after treatment showed dose-dependent upregulation of MMP-9 activity. No differences in the growth profile of ET-treated cells were noted, and all cultures reached 75-80\% confluence within the same time frame. The abundant MMP-2 levels noted in the conditioned media of a SCp2 are comparable to basal levels in growth medium (GM). (b, d) Bar graphs represent the quantification of fold increase in peak area of MMP-9 bands shown in the respective zymograms. Each bar represents triplicate analyses of mean $\pm \mathrm{SD}$; ${ }^{* * *} P<0.001$ compared to the untreated control.

ET had an 18 -fold increase $\left(1.8 \mathrm{pg} / 10^{6}\right.$ cells) in their conditioned media compared to untreated controls (Figure 2(d)).

\subsection{Long-Term, but Not Short-Term, Endotoxin Treatment} Enhances Migration of Normal Mouse Mammary Epithelial Cells (SCp2) and Human Breast Cancer Cells (MCF-7 and $M D A-M B-231)$. Wound healing assay showed that the wounded area noted in the short-term treated SCp2 cells was not significantly different when compared to untreated controls. However, long-term exposure to $0.1 \mu \mathrm{g} / \mathrm{ml}$ ET enhanced the closure of the wound, whereby $66 \%$ of the wounded area was repopulated with migrating cells, compared to only $41 \%$ in untreated controls 48 hours after wounding (Figures 3(a) and 3(b)). After noting the response of nontumorigenic mammary cells to ET exposure, we opted to investigate the effect of ET treatment $(1 \mu \mathrm{g} / \mathrm{ml})$ on modulating migration and proliferation of human breast cancer low invasive MCF-7 and highly invasive MDA-MB-231 cells. Interestingly, long-term, but not short-term, exposure to $1 \mu \mathrm{g} / \mathrm{ml}$ ET enhanced the proliferation rate of MCF-7 and MDA-MB-231 cells. Short-term ET treatment did not significantly enhance the proliferation rate, while the number of cells exposed to long-term ET treatment was $\sim 5$ and 1.9 times greater than that of untreated MCF-7 (Figure 3(c)) and MDA-MB-231 cells (Figure 3(d)), respectively. In MCF-7 cells, short-term exposure to $1 \mu \mathrm{g} / \mathrm{ml}$ ET had a marginal, yet significant, effect while long-term exposure to $1 \mu \mathrm{g} / \mathrm{ml}$ ET markedly enhanced the closure of the wound compared to the untreated control; $50 \%$ of the wounded area was repopulated with migrating cells, compared to only $28 \%$ in untreated controls at 48 hours after wounding (Figures 3(e) and 3(f)). On the other hand, closure of the wounded area noted in the short-term treated MDA-MB-231 cells was not significantly different when compared to the untreated control; however, long-term exposure to $1 \mu \mathrm{g} / \mathrm{ml}$ ET enhanced the closure of the wound compared to untreated controls, whereby $72 \%$ of the wounded area was repopulated with migrating cells, compared to only $33 \%$ in untreated controls at 48 hours after wounding (Figures $3(\mathrm{~g})$ and $3(\mathrm{~h})$ ). It is worth noting that longterm treatment of ET on low invasive MCF-7 cells had a more pronounced effect on enhancing proliferation (5-fold) than invasion (1.6-fold), whereas ET treatment of highly invasive MDA-MB-231 cells equally enhanced (2-fold) migration and proliferation.

3.4. Endotoxin Preferentially Enhances Invasion in Pretumorigenic Human Breast Epithelial Cx43-KO S1 Cells. Recent studies in our laboratory showed that the loss of expression of the gap junction protein connexin $43(\mathrm{Cx} 43)$ triggered cell cycle entry and invasion through basement membrane in the nontumorigenic human breast epithelial S1 cells [19]. To determine the effect of ET treatment on invasion, transwell cell invasion assay was performed. Untreated Cx43KO S1 cells acquired $\sim 1.8$-fold increase in their invasion capacity compared to control untreated S1 cells (Figures 4(a) and 4(b)). This enhanced invasion capacity was consistent with 


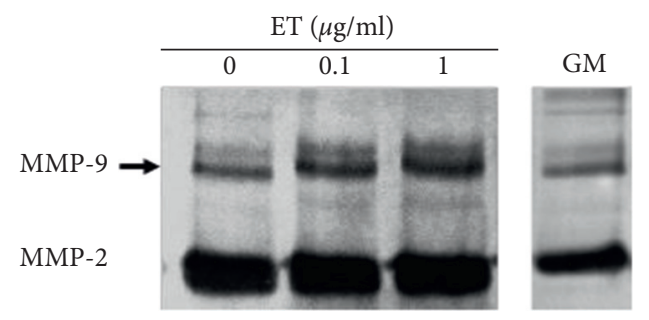

(a)

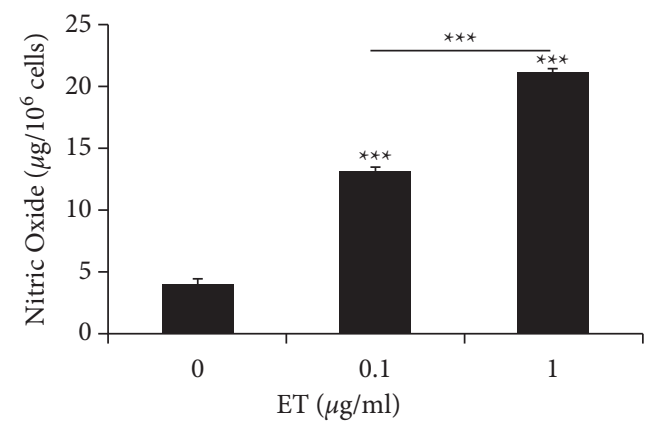

(c)

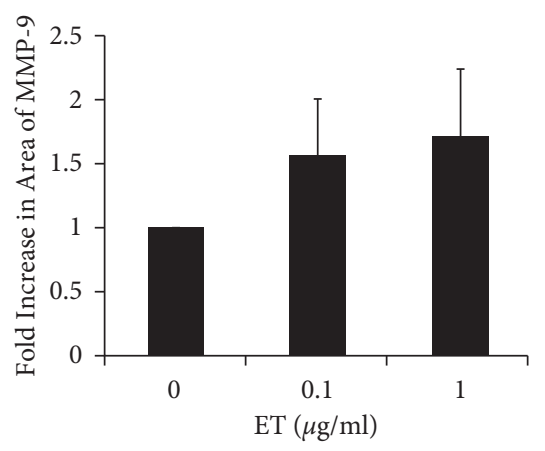

(b)

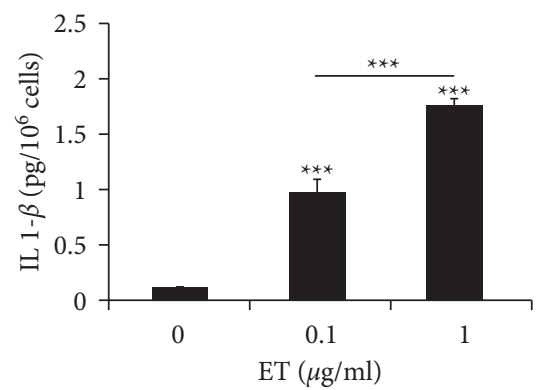

(d)

FIGURE 2: Short-term endotoxin treatment upregulates levels of inflammatory mediators produced by MDA-MB-231 human breast cancer cells. (a) Gelatin zymography of conditioned media collected from untreated control $(0 \mu \mathrm{g} / \mathrm{ml})$ and ET-treated cells $(0.1$ and $1 \mu \mathrm{g} / \mathrm{ml})$ upon reaching 75\% confluence after treatment showed upregulation of MMP-9 activity in MDA-MB-231 cells. No differences in the growth profile of ET-treated cells were noted, and all cultures reached $75-80 \%$ confluence within the same time frame. (b) Quantification of fold increase in peak area of MMP-9 bands shown in the previous zymogram. Each bar represents triplicate analyses of mean \pm SD. The abundant unregulated MMP-2 levels noted in the conditioned media are also noted in growth medium (GM). (c) Upregulation of NO and (d) IL 1- $\beta$ levels in MDA-MB-231 conditioned media collected from ET-treated cells $(0.1$ and $1 \mu \mathrm{g} / \mathrm{ml})$ compared to untreated controls $(0 \mu \mathrm{g} / \mathrm{ml})$, upon reaching $75 \%$ confluence after treatment. Each bar represents triplicate analyses of mean $\pm \mathrm{SD} .{ }^{* * *} P<0.001$ compared to the untreated control.

previous studies in our laboratory [19]. Short-term (9-day) and long-term (one-month) ET treatment of S1 cells induced around 1.5 -fold increase in the invasion capacity of $S 1$ cells, compared to control untreated cells (Figure 4(b)). Interestingly, Cx43-KO S1 cells subjected to short-term ET treatment showed $\sim 2.2$-fold increase in their ability to invade through the Matrigel, while the long-term exposure led to $\sim 2.8$-fold increase in the invasion capacity of ET-treated Cx43-KO S1 cells, compared to control untreated S1 cells (Figure 4(b)).

It is noteworthy that the activity levels of basal MMP-9 secreted by $\mathrm{Cx} 43-\mathrm{KO} \mathrm{S} 1$ were higher compared to those of S1 cells. Cx43-KO S1 cells exhibit a faster rate of proliferation [19]. Thus, correcting for a 30\% difference in cell numbers noted in Cx43-KO S1 compared to S1 cells, we detected a 7fold increase in MMP-9 activity in Cx43-KO S1 medium as compared to that of S1 cells (Figures 4(c) and 4(d)). In addition, $\mathrm{Cx} 43-\mathrm{KO} S 1$ cells consistently maintained higher levels of MMP-9 activity, compared to S1 cells upon short-term and long-term ET treatment (Figures 4(e) and 4(f)).

3.5. Endotoxin Treatment Disrupts Lumen Formation in Nontumorigenic Human Breast Epithelial S1 Acini. S1 cells in $3 \mathrm{D}$ cultures organize into differentiated monolayer acini surrounding a lumen, with a well-established apical polarity [23]. We have previously demonstrated that the loss of $\mathrm{Cx} 43$ expression disrupts this S1 cell normal acinar morphology and epithelial cell polarity [21]. To determine whether ET treatment could influence the organization of the breast epithelium, S1 cells were subjected to short-term and longterm treatment, after which acinar morphogenesis and lumen formation were assessed. While $64 \%$ of the control untreated S1 acini displayed typical lumen structures enclosed within a single layer of cells (Figure 5(a) control and 5(d) control), only $40-45 \%$ of the S1 acini treated for short and long periods with $10 \mu \mathrm{g} / \mathrm{ml}$ ET had normal morphology with undisrupted lumen demonstrating that ET treatment disrupted acinar morphology (Figures 5(b) and $5(c))$.

\subsection{Endotoxin Treatment Disrupts $\beta$-Catenin Localization in} S1 Acini. Data from our laboratory has shown that S1 acini with correct morphology display apicolateral distribution of $\beta$-catenin and gap junctional complexes [21] (Figure 5(d) control and 6(a) control). Consequently, we determined whether ET treatment would induce $\beta$-catenin mislocalization in S1 acini. This indeed was noted in acini with 


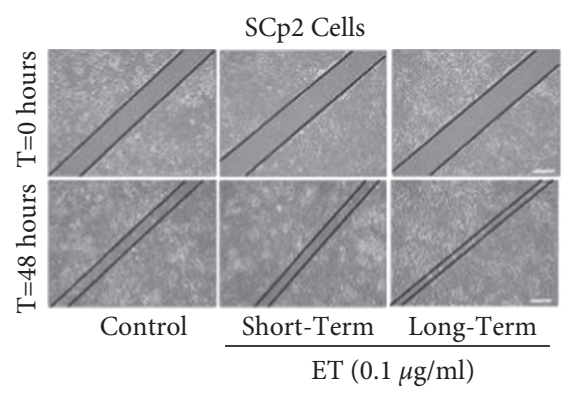

(a)

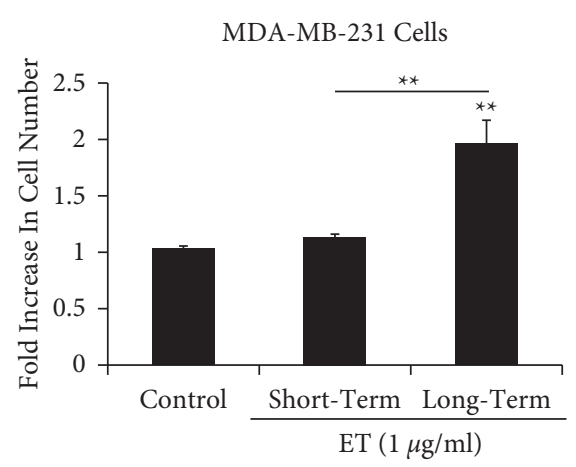

(d)

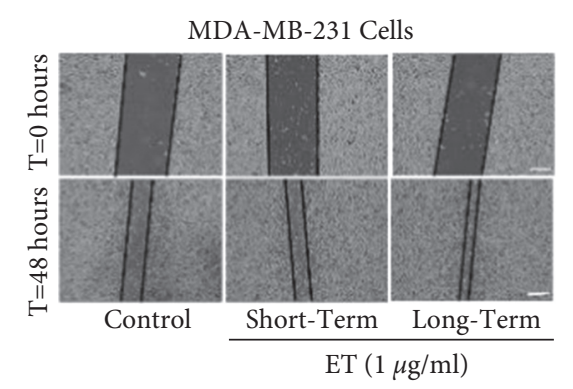

(g)

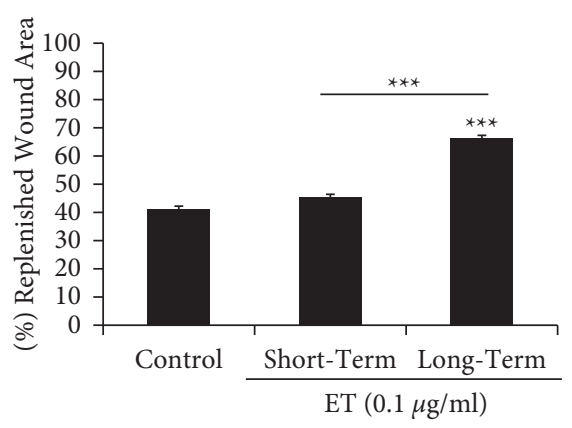

(b)

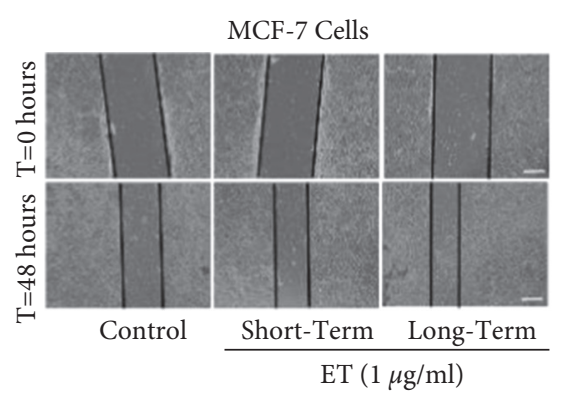

(e)

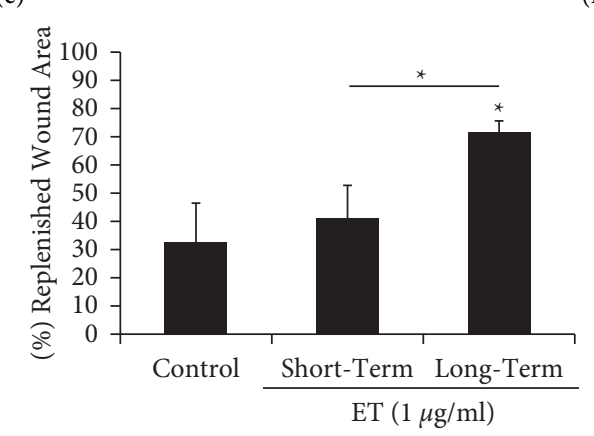

(h)

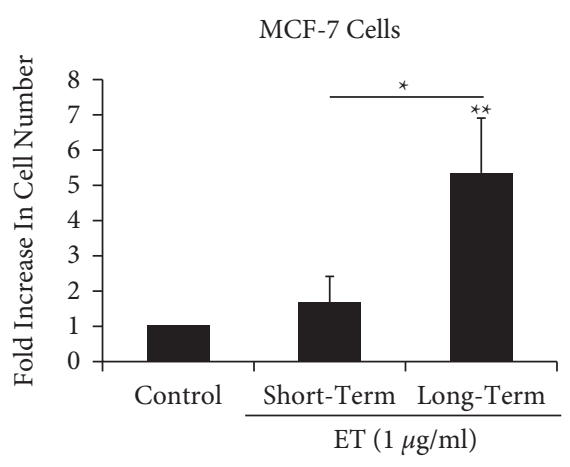

(c)

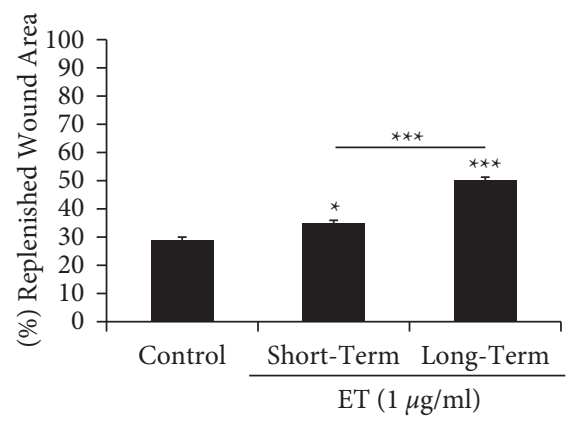

(f)

FIGURE 3: Long-term endotoxin treatment enhances migration of normal mouse mammary epithelial cells (SCp2) and human breast cancer cells (MCF-7 and MDA-MB-231). (a) Wound healing assay showed enhanced replenishment of wound area with migrating SCp2 cells upon long-term exposure (for one month) to $0.1 \mu \mathrm{g} / \mathrm{ml} \mathrm{ET}$, as opposed to short-term exposure (for 48 hours after wounding) or untreated controls $(0 \mu \mathrm{g} / \mathrm{ml})$. (b) Bar graph shows the percentage of the replenished wound area with migrating SCp2 cells upon short-term and long-term exposure to $0.1 \mu \mathrm{g} / \mathrm{ml}$ ET relative to untreated controls, for 48 hours after wounding. (c) Long-term exposure to $1 \mu \mathrm{g} / \mathrm{ml} \mathrm{ET} \mathrm{increased} \mathrm{the}$ proliferation rate of MCF-7 and (d) MDA-MB-231 cells, as opposed to short-term exposure, where the increase in cell count was not significant when compared to untreated controls $(0 \mu \mathrm{g} / \mathrm{ml})$. Wound healing assay showed enhanced migration of (e, f) MCF-7 upon short (albeit marginal) and long-term exposures and ( $\mathrm{g}, \mathrm{h}$ ) MDA-MB-231 upon long-term exposure to $1 \mu \mathrm{g} / \mathrm{ml}$ ET, when compared to untreated controls $(0 \mu \mathrm{g} / \mathrm{ml})$. Scale bar $=100 \mu \mathrm{m}$. Each bar represents triplicate analyses of mean $\pm \mathrm{SD} .{ }^{*} P<0.05 ;{ }^{* *} P<0.01 ;{ }^{* * *} P<0.001$ compared to the untreated control.

disrupted lumen, whether in control untreated (data not shown) or short-term or long-term ET-treated acini, whereby $\beta$-catenin was redistributed across the entire cell membrane (Figure 5(d)). Interestingly, among the S1 acini with monolayered lumen in the control group (Figure 6(a)), $\sim 60 \%$ showed apicolateral localization of $\beta$-catenin (Figure 6(a) top lane), while the remaining $\sim 40 \%$ had more prominent lateral and basal redistribution of $\beta$-catenin (Figure 6(b)). This ratio was not significantly altered following short-term exposure to ET; however, upon long-term
ET exposure, only $\sim 48 \%$ of the S1 acini with monolayered lumen maintained apicolateral localization of $\beta$-catenin, while those with more prominent lateral and basal redistribution increased to $\sim 52 \%$ (Figure 6(b)).

\section{Discussion}

Despite the presence of previous research associating chronic inflammation with malignant transformation in many tissues [15], little is known about the effect of 

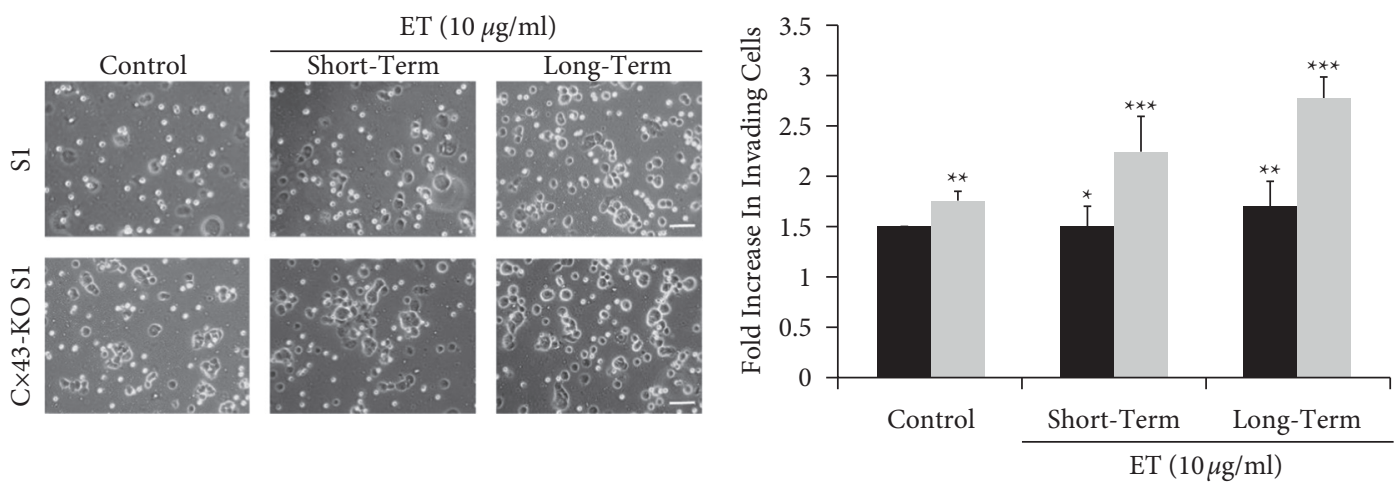

S1

C $\times 43-K O ~ S 1$

(a)

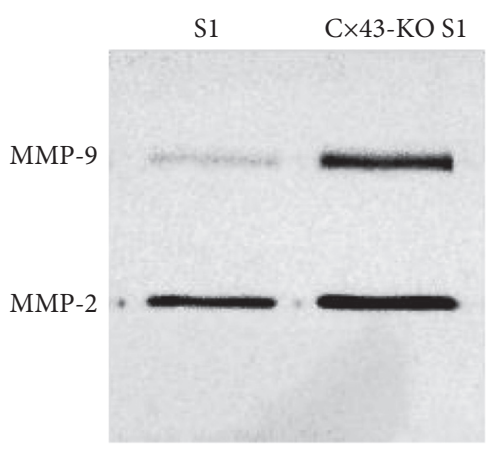

(c)

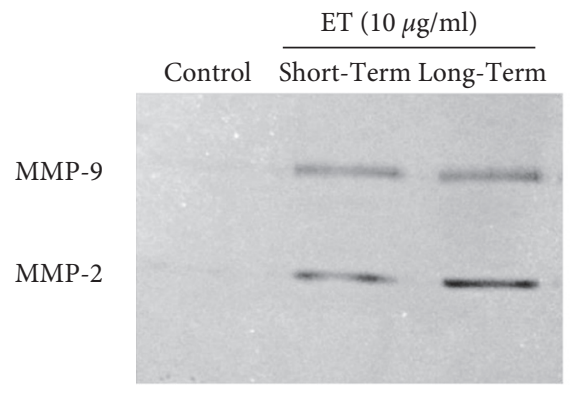

S1 (b)

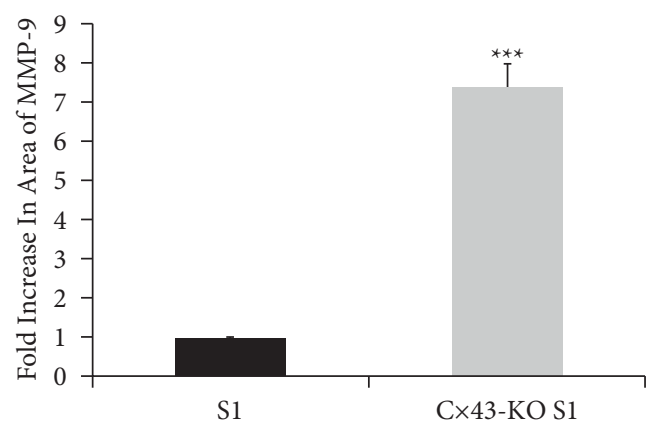

(d)

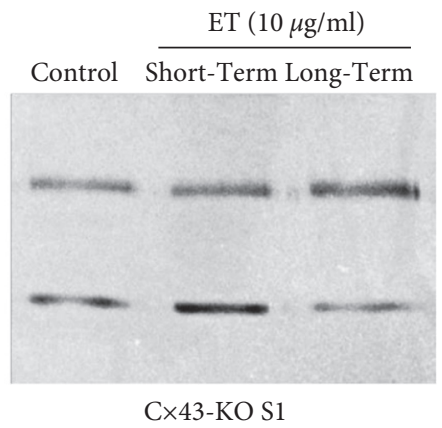

$\mathrm{C} \times 43-\mathrm{KO} S 1$

(e)

Figure 4: Continued. 


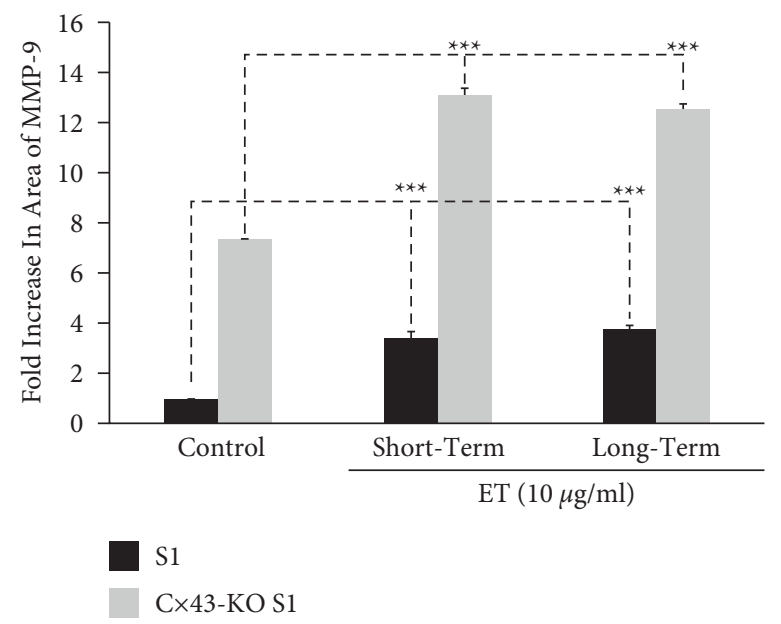

(f)

Figure 4: Pretumorigenic Cx43-KO S1 human breast epithelial cells secrete higher levels of MMP-9, and their invasive ability is enhanced upon endotoxin exposure more than their nontumorigenic S1 counterparts. (a) Short-term and long-term exposures of S1 and Cx43-KO S1 cells to $10 \mu \mathrm{g} / \mathrm{ml}$ ET enhanced the invasion across Matrigel. Scale bar is $10 \mu \mathrm{m}$. (b) Fold increase in the number of invading cells subjected to short-term and long-term ET treatment at $10 \mu \mathrm{g} / \mathrm{ml}$ ET relative to untreated controls $(0 \mu \mathrm{g} / \mathrm{ml})$. (c) Gelatin zymography of untreated S1 and Cx43-KO S1 media collected from 2D cultures upon reaching 75\% confluence showed upregulation of MMP-9 activity in Cx43-KO S1 compared to S1 cells. (d) Quantification of fold increase in peak area of MMP-9 bands shown in the previous zymogram, corrected for the $30 \%$ increase in cell counts observed with Cx43-KO S1 compared to S1 cells. (e) Gelatin zymography and (f) quantification of fold increase in peak area of MMP-9 bands of conditioned media collected from 2D cultures of S1 and Cx43-KO S1 cells, including untreated controls $(0 \mu \mathrm{g} / \mathrm{ml})$ and ET-treated $(10 \mu \mathrm{g} / \mathrm{ml})$ cells, upon reaching $75 \%$ confluence after treatment and after long-term exposure (one month), corrected for the $30 \%$ increase in cell counts of $\mathrm{Cx} 43-\mathrm{KO}$ S1 compared to S1 cells. Results showed upregulation of MMP-9 activity in S1 and Cx43-KO S1 culture media after both ET exposures, as compared to untreated controls of each cell type. Samples of each cell type were run on the same gel and under the same conditions. Each bar represents triplicate analyses of mean $\pm \mathrm{SD} .{ }^{*} P<0.05 ;{ }^{* *} P<0.01 ;{ }^{* * *} P<0.001$ compared to the untreated control.

inflammation on breast cancer initiation or progression. Whether inflammation might trigger tumor initiation events, noted by loss of normal morphological features of mammary epithelium, cell cycle entry, and enhanced migration and invasion [21], is not well known. Our study investigates the role of ET-induced inflammatory insult in breast cancer initiation events using nontumorigenic (SCp2 and $\mathrm{S1}$ ) rodent mammary and human breast epithelial cells, respectively, and whether such an insult can "add injury" to pretumorigenic (Cx43-KO S1) or tumorigenic breast cells (MCF-7 and MDA-MB-231).

4.1. Inflammation and Breast Cancer. The use of ET in in vitro and in vivo models to simulate inflammation-like conditions is widely accepted. In vitro, ET was shown to induce inflammatory phenotype in alveolar epithelial cells [24], umbilical vein endothelial cells [25], and bovine and rodent mammary epithelial cells [18, 26, 27], in addition to stimulating macrophages [28, 29], T cells [30], and B cells [31] from different species. In vivo, ET induced mastitis in several animal models, when introduced into the mammary gland of sheep [32], goat [33,34], and cows [35, 36].

In line with our current findings, previous studies showed that ET exposure modulated the function of both normal and tumorigenic cells. ET inhibited the expression of the differentiation marker $\beta$-casein, activated NF- $\kappa \mathrm{B}$, increased gelatinase activity, and stimulated the production of
NO and inflammatory cytokines, such as IL-6 and tumor necrosis factor $\alpha$ (TNF- $\alpha$ ), in nontumorigenic mouse mammary SCp2 and CID-9 cells $[17,18]$. In tumorigenic cells, ET induced tumor angiogenesis via increased IL- 6 and VEGF production by stromal fibroblasts isolated from colon cancer [37] and enhanced lung metastasis in a xenograft mouse model [38]. Moreover, plasma collected from ETstimulated human and rodent blood was shown to activate the NF- $\kappa \mathrm{B}$ pathway and to enhance migration of prostate cancer cells in vitro [11].

Long-term ET treatment augmented proliferation and migration of moderately (MCF-7) and highly invasive human breast cancer cells (MDA-MB-231), suggesting that inflammation enhances tumorigenicity of breast cancer cells. Indeed, inflammation has been reported to accelerate tumor progression in mouse models of breast cancer (reviewed by [39]). Moreover, chemotherapy-induced inflammation was reported as a main contributor to chemoresistance and metastasis in both syngeneic and xenograft breast cancer models [40]. Trivanović et al. demonstrated that MCF-7 cells acquire epithelial-to-mesenchymal transition (EMT) properties after exposure to conditioned media collected from inflammation-primed human adipose cells [41]. Similarly, Hong et al. demonstrated that ET treatment induces an EMT-like phenotype in MDA-MB-231 cells, leading to enhanced migration and invasion [42]. Our results are further supported by the previously proposed mechanism involving Toll-like receptor 4 (TLR4), overexpressed in 


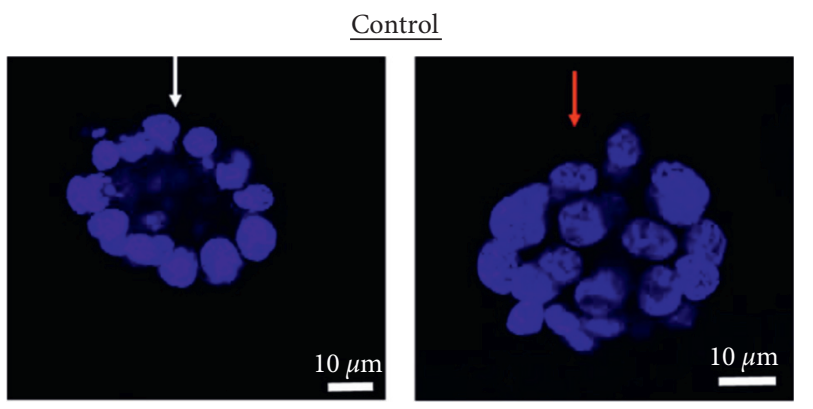

(a)

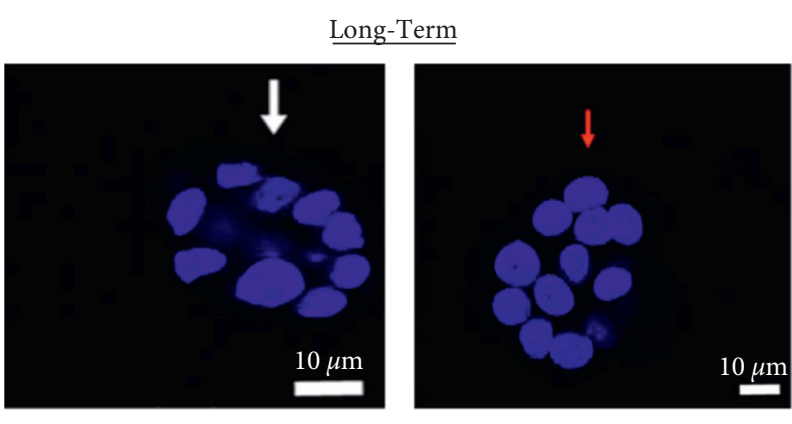

(b)

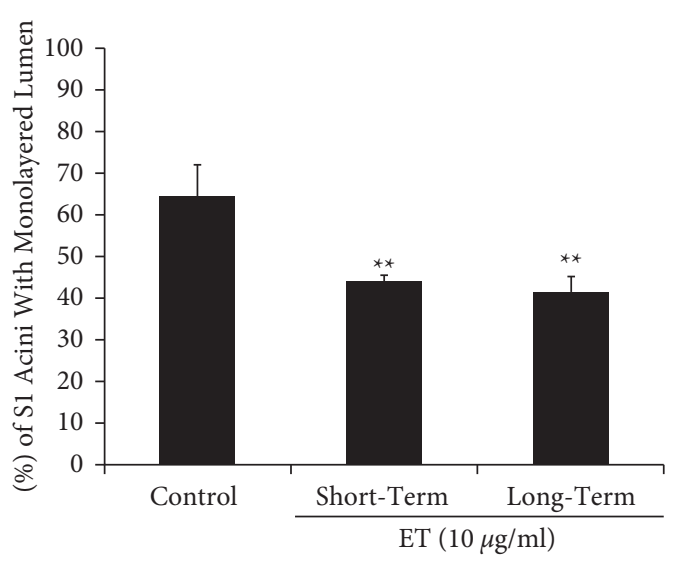

(c)

FIgURE 5: Continued. 

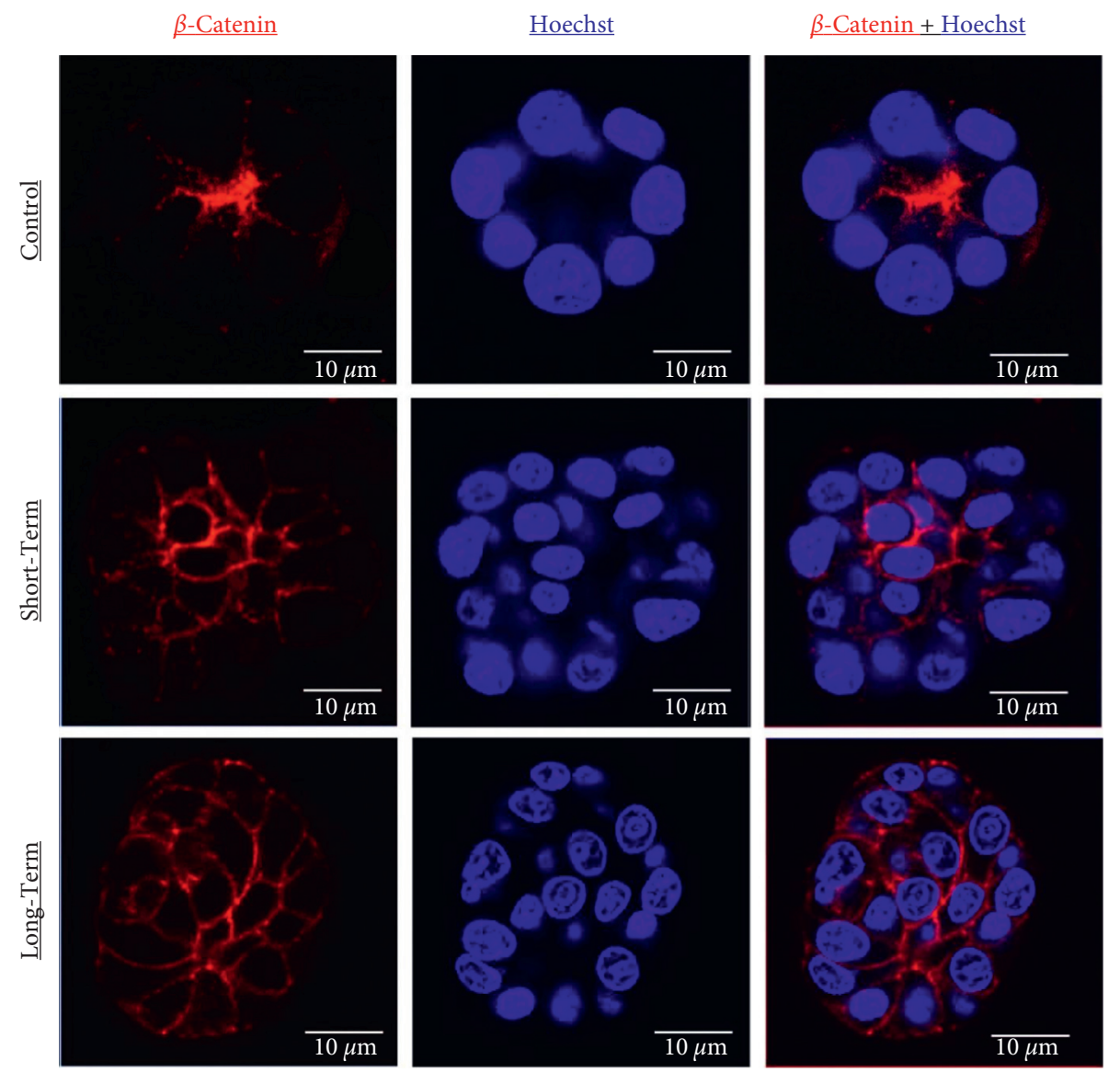

(d)

FIGURE 5: Endotoxin disrupts lumen formation in 3D cultures of human breast epithelial S1 cells. Acini of (a) control untreated S1 cells $(0 \mu \mathrm{g} / \mathrm{ml})$ and (b) S1 cells subjected to long-term ET treatment at $10 \mu \mathrm{g} / \mathrm{ml}$ were stained with Hoechst (blue) on day 11 and scored for lumen formation. White arrows point at acini with normal monolayered lumen, while red arrows point at those with disrupted multilayered lumen. (c) Bar graph shows percentages of acini with undisrupted monolayered lumen in control untreated S1 cells and those subjected to shortterm as well as long-term ET treatment at $10 \mu \mathrm{g} / \mathrm{ml}$. One hundred acini were scored for each condition in every replicate. Each bar represents triplicate analyses of mean \pm SD. ${ }^{* *} P<0.01$ compared to the untreated control. (d) Representative S1 acini immunostained for $\beta$-catenin (red) and counterstained with Hoechst (blue). The upper lane shows a control untreated S1 acinus with undisrupted monolayered lumen and apicolateral $\beta$-catenin localization. The middle lane shows an S1 acinus following short-term ET treatment at $10 \mu \mathrm{g} / \mathrm{ml}$, and the lower lane shows an S1 acinus following long-term ET treatment at $10 \mu \mathrm{g} / \mathrm{ml}$. Both short-term and long-term treatments reveal higher abundance of multilayered acini devoid of lumen, with relocalization of $\beta$-catenin across the entire cell membrane.

breast cancer patients with lymph node metastasis, that was induced in both ET-treated human breast cancer cells, MCF7 and MDA-MB-231, resulting in increased invasiveness [43]. Indeed, TLR4 induces the expression of T-LAK cellOriginated Protein Kinase (TOPK) that has been proposed to regulate MMP-9 gelatinase expression and activity, thus acting as key mediator of ET-induced migration and invasion of human breast adenocarcinoma cell lines [44].

\subsection{Inflammatory Microenvironment and Cell Phenotype.} The cellular microenvironment plays a major role in transitioning into a transformed phenotype [45]. Specifically, an inflammatory insult, which enhances the expression of cytokines and MMPs, may induce dedifferentiation and loss of normal tissue phenotype, an early sign of breast cancer $[46,47]$. It is noteworthy that obesity was shown to trigger breast adipose tissue inflammation, leading to increased risk of breast cancer $[48,49]$, and has been associated with loss of the apical distribution of $\mathrm{Cx} 43$ in 3D cultures of S1 breast epithelial cells, mitotic spindle orientation (MSO), and induced proliferation and multilayering in S1 acini $[19,21]$. This oncogenic effect is believed to be mediated by the fat tissue-derived adipokine leptin [50, 51]. Interestingly, we demonstrated that ET treatment of S1 acini impaired the normal morphogenesis, as indicated by the disrupted formation of monolayered lumen in 3D cultures of S1 cells and the altered localization of $\beta$-catenin. Our lab has previously shown that the loss of $\mathrm{Cx} 43$ expression in S1 cells triggers cell cycle entry and invasion through basement membrane $[19,21]$. While ET treatment upregulated the activity of MMP-9 and concomitantly enhanced the invasion of S1 cells, those effects were more pronounced in their Cx43KO S1 pretumorigenic counterparts. This suggests that 


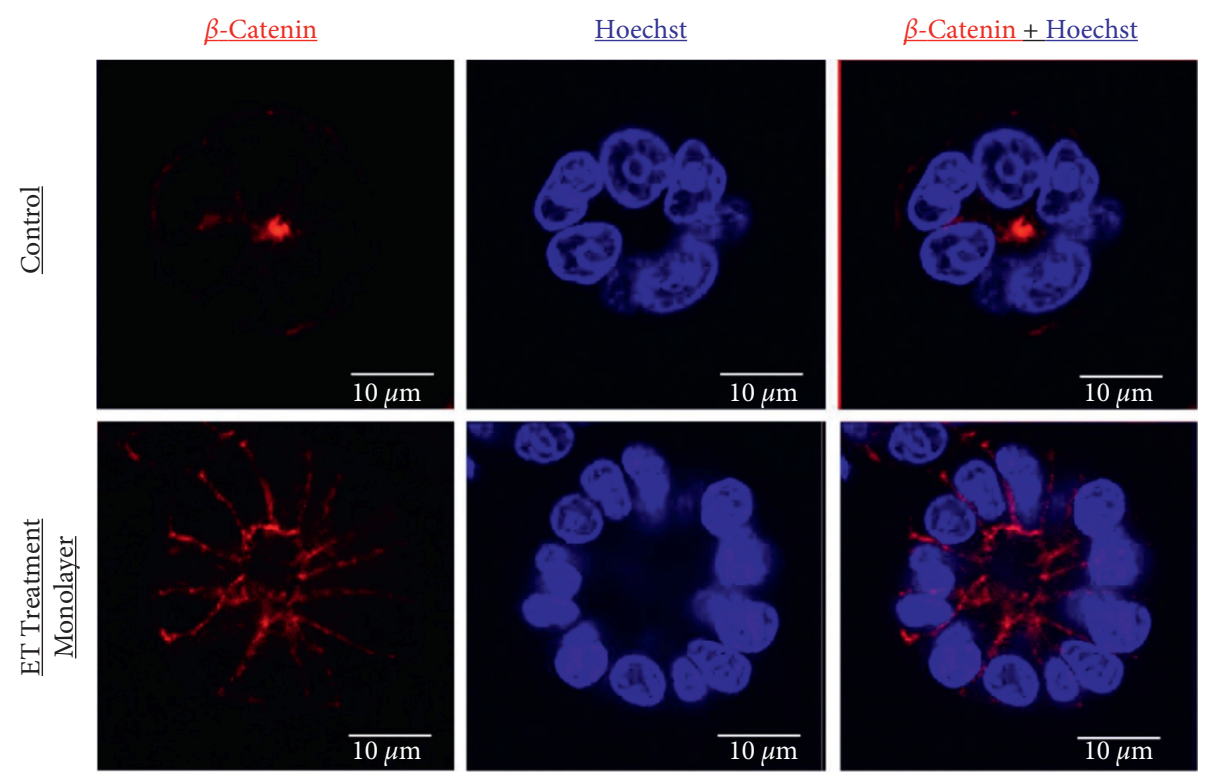

(a)

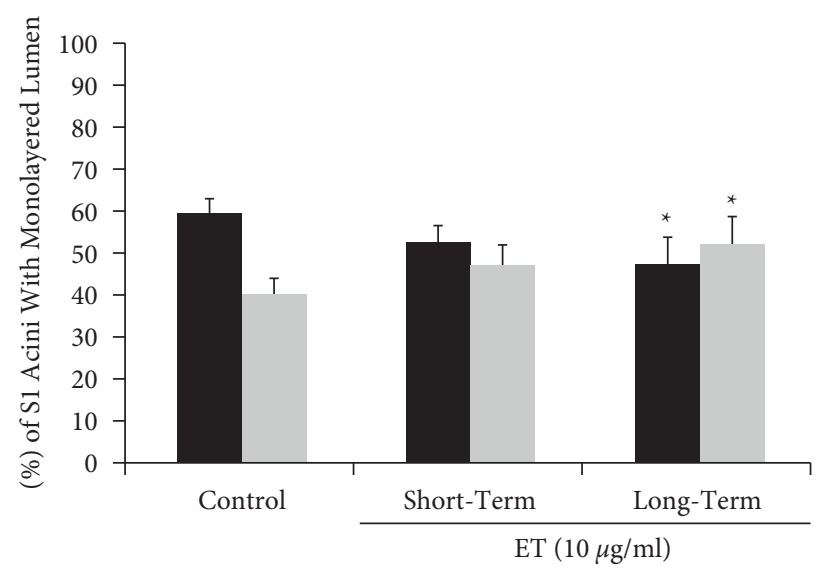

$\beta$-catenin localization

Apicolateral

Basolateral

(b)

FIgURE 6: Long-term endotoxin treatment alters $\beta$-catenin localization in 3D cultures of human breast epithelial S1 cells. (a) Representative S1 acini immunostained for $\beta$-catenin (red) and counterstained with Hoechst (blue). The upper lane shows a control untreated S1 acinus with undisrupted monolayered lumen and apicolateral $\beta$-catenin localization. The lower lane shows an S1 acinus following ET treatment at $10 \mu \mathrm{g} / \mathrm{ml}$ revealing relocalization of $\beta$-catenin from the apicolateral to the lateral and basolateral domain while maintaining undisrupted monolayered lumen. (b) Quantification data of $\beta$-catenin localization shows significant redistribution of $\beta$-catenin from the apicolateral to the basolateral domain in S1 acini with monolayered lumen after long-term ET treatment at $10 \mu \mathrm{g} / \mathrm{ml}$. Localization of $\beta$-catenin was evaluated under confocal microscopy. One hundred acini with monolayered lumen from every replicate were visualized, and each acinus was scored for polarity based on the $\beta$-catenin (red) localization as apicolateral versus basolateral. Each bar represents triplicate analyses of mean \pm SD. ${ }^{*} P<0.05$ compared to the untreated control.

pretumorigenic breast cells are more sensitive to ET insults than normal cells and indicates that an inflammatory microenvironment adds injury to tumor-initiated cells. An earlier study by Riccardi et al. highlighted the effect of inflammation on cancer progression, whereby neoplastic epithelial cells acquired a mesenchymal phenotype through inflammatory stimuli. The mesenchymal phenotype was manifested as immune-regulatory functions and other immune-inhibitory properties, typically expressed by mesenchymal-stromal cells, which lead to tumor immune escape and cancer progression [52].

\section{Conclusion}

In conclusion, this study shows that ET-induced inflammation triggers or enhances tumor initiation events in nontumorigenic and pretumorigenic breast epithelia, respectively, and enhances tumorigenicity of breast cancer 
cells. Our findings highlight the role of inflammation in inducing cancer initiation events, portrayed as loss of normal differentiated morphology in 3D cultures of nontumorigenic breast cells, in addition to increasing the migratory and invasive abilities. Our study also suggests that such inflammatory insults can "add injury" to pretumorigenic and tumorigenic breast cells. Future studies should focus on studying the tumor-initiating ability of ET-treated Cx43-KO S1 cells, and the tumor-enhancing ability of ETtreated MDA-MB-231 and MCF-7 cells in vivo as compared to their untreated counterparts.

\section{Data Availability}

Data sharing is not applicable to this article as no datasets were generated or analyzed during the current study.

\section{Conflicts of Interest}

RST and NN are members of the International Breast Cancer and Nutrition (IBCN) project at Purdue University.

\section{Acknowledgments}

The authors are grateful to Rita Kalot and Angela Mermerian for critically reading the manuscript. This work was supported by a grant from the Kamal A. Shair Central Research Science Laboratory (KAS CRSL) Research Fund, University Research Board (URB) at the American University of Beirut, Lebanon, and National Council for Scientific Research, Lebanon (CNRS-L).

\section{References}

[1] S. I. Grivennikov, F. R. Greten, and M. Karin, "Immunity, inflammation, and cancer," Cell, vol. 140, no. 6, pp. 883-899, 2010.

[2] T. Hagemann, F. Balkwill, and T. Lawrence, "Inflammation and cancer: a double-edged sword," Cancer Cell, vol. 12, no. 4, pp. 300-301, 2007.

[3] C.-H. R. Choi, I. Al Bakir, N.-S. Ding et al., "Cumulative burden of inflammation predicts colorectal neoplasia risk in ulcerative colitis: a large single-centre study," Gut, vol. 68, no. 3, pp. 414-422, 2019.

[4] S. H. Itzkowitz and X. Yio, "Inflammation and cancer IV. Colorectal cancer in inflammatory bowel disease: the role of inflammation," American Journal of Physiology-Gastrointestinal and Liver Physiology, vol. 287, no. 1, pp. G7-G17, 2004.

[5] L. X. Yu, Y. Ling, and H. Y. Wang, "Role of nonresolving inflammation in hepatocellular carcinoma development and progression," NPJ Precision Oncology, vol. 2, no. 1, pp. 6-10, 2018.

[6] F. Wang, W. Meng, B. Wang, and L. Qiao, "Helicobacter pylori-induced gastric inflammation and gastric cancer," Cancer Letters, vol. 345, no. 2, pp. 196-202, 2014.

[7] J. H. Harmey, C. D. Bucana, W. Lu et al., "Lipopolysaccharideinduced metastatic growth is associated with increased angiogenesis, vascular permeability and tumor cell invasion," International Journal of Cancer, vol. 101, no. 5, pp. 415-422, 2002.

[8] S. D. Killeen, J. H. Wang, E. J. Andrews, and H. P. Redmond, "Bacterial endotoxin enhances colorectal cancer cell adhesion and invasion through TLR- 4 and NF- $\kappa$ B-dependent activation of the urokinase plasminogen activator system," British Journal of Cancer, vol. 100, no. 10, pp. 1589-1602, 2009.

[9] X. Liu, J. Liang, and G. Li, "Lipopolysaccharide promotes adhesion and invasion of hepatoma cell lines HepG2 and HepG2.2.15," Molecular Biology Reports, vol. 37, no. 5, pp. 2235-2239, 2010.

[10] C.-H. Liu, K. Chen, and Y. Di, “Abstract 1094: lipopolysaccharide-induced chronic inflammation promotes lung tumorigenesis in the context of an immunosuppressive microenvironment," Cancer Research, vol. 79, no. 13 Supplement, p. 1094, 2019.

[11] S. Jain, P. Dash, A. P. Minz et al., "Lipopolysaccharide (LPS) enhances prostate cancer metastasis potentially through NF$\kappa \mathrm{B}$ activation and recurrent dexamethasone administration fails to suppress it in vivo," The Prostate, vol. 79, no. 2, pp. 168-182, 2019.

[12] R. L. Siegel, K. D. Miller, and A. Jemal, "Cancer statistics, 2019," CA: A Cancer Journal for Clinicians, vol. 69, no. 1, pp. 7-34, 2019.

[13] D. K. Tobias, A. O. Akinkuolie, P. D. Chandler et al., "Markers of inflammation and incident breast cancer risk in the women's health study," American Journal of Epidemiology, vol. 187, no. 4, pp. 705-716, 2018.

[14] L. Guo, S. Liu, S. Zhang et al., "C-reactive protein and risk of breast cancer: a systematic review and meta-analysis," Scientific Reports, vol. 5, no. 1, Article ID 10508, 2015.

[15] M. Ham and A. Moon, "Inflammatory and microenvironmental factors involved in breast cancer progression," Archives of Pharmacal Research, vol. 36, no. 12, pp. 1419-1431, 2013.

[16] D. R. Brenner, D. Scherer, K. Muir et al., "A review of the application of inflammatory biomarkers in epidemiologic cancer research," Cancer Epidemiology Biomarkers \& Prevention, vol. 23, no. 9, pp. 1729-1751, 2014.

[17] S. W. Maalouf, R. S. Talhouk, and F. L. Schanbacher, "Inflammatory responses in epithelia: endotoxin-induced IL-6 secretion and iNOS/NO production are differentially regulated in mouse mammary epithelial cells," Journal of Inflammation, vol. 7, no. 1, p. 58, 2010.

[18] B. Safieh-Garabedian, G. M. Mouneimne, W. El-Jouni, M. Khattar, and R. Talhouk, "The effect of endotoxin on functional parameters of mammary CID-9 cells," Reproduction, vol. 127, no. 3, pp. 397-406, 2004.

[19] S. Fostok, M. El-Sibai, D. Bazzoun, S. Lelièvre, and R. Talhouk, "Connexin 43 loss triggers cell cycle entry and invasion in non-neoplastic breast epithelium: a role for non-canonical wnt signaling," Cancers, vol. 11, no. 3, 2019.

[20] R. S. Talhouk, J. R. Chin, E. N. Unemori, Z. Werb, and M. J. Bissell, "Proteinases of the mammary gland: developmental regulation in vivo and vectorial secretion in culture," Development, vol. 112, no. 2, pp. 439-449, 1991.

[21] D. Bazzoun, H. A. Adissu, L. Wang et al., "Connexin 43 maintains tissue polarity and regulates mitotic spindle orientation in the breast epithelium," Journal of Cell Science, vol. 132, no. 10, 2019.

[22] R. S. Talhouk, R. Mroue, M. Mokalled et al., "Heterocellular interaction enhances recruitment of $\alpha$ and $\beta$-catenins and ZO2 into functional gap-junction complexes and induces gap junction-dependant differentiation of mammary epithelial cells," Experimental Cell Research, vol. 314, no. 18, pp. 3275-3291, 2008.

[23] S. A. Lelièvre, V. M. Weaver, J. A. Nickerson et al., "Tissue phenotype depends on reciprocal interactions between the 
extracellular matrix and the structural organization of the nucleus," Proceedings of the National Academy of Sciences of the United States of America, vol. 95, no. 25, Article ID 14711, 1998.

[24] J. J. Haddad and S. C. Land, "Nuclear factor- $\kappa$ b blockade attenuates but does not abrogate lipopolysaccharide-dependent tumor necrosis factor- $\alpha$ biosynthesis in alveolar epithelial cells," Biochemical and Biophysical Research Communications, vol. 285, no. 2, pp. 267-272, 2001.

[25] J. Pugin, C. C. Schurer-Maly, D. Leturcq, A. Moriarty, R. J. Ulevitch, and P. S. Tobias, "Lipopolysaccharide activation of human endothelial and epithelial cells is mediated by lipopolysaccharide-binding protein and soluble CD14," Proceedings of the National Academy of Sciences, vol. 90, no. 7, pp. 2744-2748, 1993.

[26] T. Okada, N. Matsuzaki, K. Sawai et al., "Chorioamnionitis reduces placental endocrine functions: the role of bacterial lipopolysaccharide and superoxide anion," Journal of Endocrinology, vol. 155, no. 3, pp. 401-410, 1997.

[27] N. Boudjellab, H. S. Chan-Tang, X. Li, and X. Zhao, "Interleukin 8 response by bovine mammary epithelial cells to lipopolysaccharide stimulation," American Journal of Veterinary Research, vol. 59, no. 12, pp. 1563-1567, 1998.

[28] D. D. Morris, N. Crowe, J. N. Moore, and L. L. Moldawer, "Endotoxin-induced production of interleukin 6 by equine peritoneal macrophages in vitro," American Journal of Veterinary Research, vol. 53, no. 8, pp. 1298-1301, 1992.

[29] Y. X. Zhang, N. Zhi, S. R. Yu, Q. J. Li, G. Q. Yu, and X. Zhang, "Protective immunity induced by $67 \mathrm{~K}$ outer membrane protein of phase I Coxiella burnetii in mice and Guinea pigs," Acta Virologica, vol. 38, no. 6, pp. 327-332, 1994.

[30] T. Mattern, A. Thanhäuser, N. Reiling et al., "Endotoxin and lipid A stimulate proliferation of human T cells in the presence of autologous monocytes," The Journal of Immunology, vol. 153, no. 7, pp. 2996-3004, 1994.

[31] R. S. Weeks and C. H. Sibley, "Inducible expression of transfected kappa light chains by lipopolysaccharide and IFNgamma in the murine B lymphoma, 70Z/3," The Journal of Immunology, vol. 140, no. 4, pp. 1312-1320, 1988.

[32] I. G. Colditz, "Induction of inflammatory responses by endotoxin in the non-lactating ovine mammary gland," Immunology \& Cell Biology, vol. 65, no. Pt 6, pp. 437-441, 1987.

[33] G. Dhondt, C. Burvenich, and G. Peeters, "Mammary blood flow during experimental Escherichia coli endotoxin induced mastitis in goats and cows," Journal of Dairy Research, vol. 44, no. 3, pp. 433-440, 1977.

[34] F. W. Lengemann and M. Pitzrick, "Endotoxin of Escherichia coli and permeability of the mammary gland of goats," Journal of Dairy Science, vol. 70, no. 1, pp. 201-208, 1987.

[35] S. P. Oliver and K. L. Smith, "Nonantibiotic approach in control of bovine mastitis during dry period," Journal of Dairy Science, vol. 65, no. 11, pp. 2119-2124, 1982.

[36] D. E. Shuster, M. E. Kehrli, and M. G. Stevens, "Cytokine production during endotoxin-induced mastitis in lactating dairy cows," American Journal of Veterinary Research, vol. 54, no. 1, pp. 80-85, 1993.

[37] T. Nagasaki, M. Hara, H. Nakanishi, H. Takahashi, M. Sato, and H. Takeyama, "Interleukin- 6 released by colon cancerassociated fibroblasts is critical for tumour angiogenesis: antiinterleukin-6 receptor antibody suppressed angiogenesis and inhibited tumour-stroma interaction," British Journal of Cancer, vol. 110, no. 2, pp. 469-478, 2014.

[38] J.-Y. Li, Z.-L. Ou, S.-J. Yu et al., "The chemokine receptor CCR4 promotes tumor growth and lung metastasis in breast cancer," Breast Cancer Research and Treatment, vol. 131, no. 3, pp. 837-848, 2012.

[39] D. Laoui, K. Movahedi, E. Van Overmeire et al., "Tumorassociated macrophages in breast cancer: distinct subsets, distinct functions," International Journal of Developmental Biology, vol. 55, no. 7-9, pp. 861-867, 2011.

[40] S. Acharyya, T. Oskarsson, S. Vanharanta et al., "A CXCL1 paracrine network links cancer chemoresistance and metastasis," Cell, vol. 150, no. 1, pp. 165-178, 2012.

[41] D. Trivanovic, A. Jaukovic, J. Krstic et al., "Inflammatory cytokines prime adipose tissue mesenchymal stem cells to enhance malignancy of MCF-7 breast cancer cells via transforming growth factor-betal," IUBMB Life, vol. 68, no. 3, pp. 190-200, 2016.

[42] D. Hong, S. Y. Jang, E. H. Jang et al., "Shikonin as an inhibitor of the LPS-induced epithelial-to-mesenchymal transition in human breast cancer cells," International Journal of Molecular Medicine, vol. 36, no. 6, pp. 1601-1606, 2015.

[43] H. Yang, B. Wang, T. Wang et al., "Toll-like receptor 4 prompts human breast cancer cells invasiveness via lipopolysaccharide stimulation and is overexpressed in patients with lymph node metastasis," PLoS One, vol. 9, no. 10, Article ID e109980, 2014.

[44] M.-A. Seol, J.-H. Park, J. H. Jeong, J. Lyu, S. Y. Han, and S.-M. Oh, "Role of TOPK in lipopolysaccharide-induced breast cancer cell migration and invasion," Oncotarget, vol. 8, no. 25, pp. 40190-40203, 2017.

[45] E. N. Wainwright and P. Scaffidi, "Epigenetics and cancer stem cells: unleashing, hijacking, and restricting cellular plasticity," Trends in Cancer, vol. 3, no. 5, pp. 372-386, 2017.

[46] R. S. Talhouk, M. J. Bissell, and Z. Werb, "Coordinated expression of extracellular matrix-degrading proteinases and their inhibitors regulates mammary epithelial function during involution," Journal of Cell Biology, vol. 118, no. 5, pp. 1271-1282, 1992.

[47] C. J. Sympson, R. S. Talhouk, C. M. Alexander et al., "Targeted expression of stromelysin-1 in mammary gland provides evidence for a role of proteinases in branching morphogenesis and the requirement for an intact basement membrane for tissue-specific gene expression [published erratum appears in J Cell Biol 1996 Feb; 132(4): following 752]," The Journal of Cell Biology, vol. 125, no. 3, pp. 681-693, 1994.

[48] E. E. Calle and R. Kaaks, "Overweight, obesity and cancer: epidemiological evidence and proposed mechanisms," Nature Reviews Cancer, vol. 4, no. 8, pp. 579-591, 2004.

[49] T. Deng, C. J. Lyon, S. Bergin, M. A. Caligiuri, and W. A. Hsueh, "Obesity, inflammation, and cancer," Annual Review of Pathology: Mechanisms of Disease, vol. 11, no. 1, pp. 421-449, 2016.

[50] S. Andò and S. Catalano, "The multifactorial role of leptin in driving the breast cancer microenvironment," Nature Reviews Endocrinology, vol. 8, no. 5, pp. 263-275, 2011.

[51] N. K. Saxena and D. Sharma, "Multifaceted leptin network: the molecular connection between obesity and breast cancer," Journal of Mammary Gland Biology and Neoplasia, vol. 18, no. 3-4, pp. 309-320, 2013.

[52] M. Ricciardi, M. Zanotto, G. Malpeli et al., "Epithelial-tomesenchymal transition (EMT) induced by inflammatory priming elicits mesenchymal stromal cell-like immunemodulatory properties in cancer cells," British Journal of Cancer, vol. 112, no. 6, pp. 1067-1075, 2015. 